\title{
COMPARATIVE STUDY ON THE TREATMENT OF DISC HERNIATIONS
}

\author{
ESTUDIO COMPARATIVO DEL TRATAMIENTO DE LAS HERNIAS DISCALES
}

ESTUDO COMPARATIVO DE TRATAMENTO DE HÉRNIAS DE DISCO

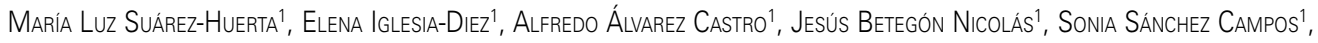
Antonio Luis Mostaza Saavedra', Manuel Fernández-González ${ }^{1}$

1. Complejo Asistencial Universitario de León, Leon, Spain.

\begin{abstract}
Objective: To compare the results of treatment of patients with low back pain and radiculalgia resulting from disc herniation associated with disc degeneration through instrumentation with pedicle screws and dynamic rod, with root release and without diskectomy compared with other non-instrumented techniques (microdiskectomy with or without foraminotomy). Methods: This is a retrospective descriptive study of interventions for patients with herniated discs in the Traumatology and Neurosurgery that used the following variables: age, sex, type of technique, surgical time, time of evolution, degree of satisfaction, and complications. Two groups were formed: instrumentation with dynamic rods and non-instrumented techniques, comparing the results of each group. The software used was the SPSS v20.0. Results: We presented 142 interventions carried out between 2009 and 2012, 86 with dynamic instrumentation and 56 by other decompression techniques without instrumentation. No statistically significant differences were observed between age and sex groups and time elapsed until intervention. We found statistically significant differences $(p=0.001)$ in surgical time, which was lower in the instrumented technique. No significant differences were found in complications between the techniques in both re-operations and in infections. Conclusions: In this study, we found no significant differences between the use of instrumentation with dynamic rods with respect to other non-instrumented surgical techniques in the treatment of herniated discs over 6 months of evolution or the complications and the degree of the patients' satisfaction.
\end{abstract}

Keyword: Intervertebral disc displacement/therapy; Diskectomy; Pedicle screws.

\section{RESUMEN}

Objetivo: Comparar los resultados del tratamiento de pacientes con lumbalgia y radiculalgia secundaria a hernia discal asociada a degeneración del disco, mediante la instrumentación con tornillos pediculares y barra dinámica, liberando la raíz sin discectomía frente a otras técnicas no instrumentadas (microdiscectomía con o sin foraminotomía). Métodos: Se ha realizado un estudio descriptivo retrospectivo de las intervenciones realizadas en pacientes con hernias discales por los servicios de Traumatología y Neurocirugía, recogiendo las siguientes variables: edad, sexo, tipo de técnica, tiempo de intervención, tiempo de evolución, grado de satisfacción y complicaciones. Se constituyeron dos grupos: instrumentación con barras dinámicas y técnicas no instrumentadas, comparando los resultados de cada grupo. Se utilizó el software SPSS v20.0. Resultados: Presentamos 142 intervenciones realizadas entre 2009 y 2012, 86 mediante instrumentación dinámica y 56 por técnicas de descompresión sin instrumentación. No se observaron diferencias estadísticamente significativas entre los grupos respecto a edad, sexo, ni tiempo de evolución hasta la intervención. Se obsenaron diferencias estadísticamente significativas $(p=0,001)$ en el tiempo de intervención, siendo menor en la técnica instrumentada. Respecto a las complicaciones de las técnicas no se hallaron diferencias significativas ni en las reintervenciones ni en las infecciones. Conclusiones: No encontramos diferencias significativas entre la utilización de instrumentación con barras dinámicas frente a otras técnicas quirúrgicas no instrumentadas en el tratamiento de las hernias discales de más de 6 meses de evolución, ni respecto a las complicaciones y ni al grado de satisfacción de los pacientes.

Descriptores: Desplazamiento del disco intervertebral/terapia; Discectomía; Tornillos pediculares.

\section{RESUMO}

Objetivo: Comparar os resultados do tratamento de pacientes com dor lombar e radiculalgia decorrente de hérnia de disco associada à degeneração do disco, por meio de instrumentação com parafusos pediculares e barra dinâmica com liberação da raiz sem discotomia em comparação com outras técnicas não instrumentadas (microdiscotomia com ou sem foraminotomia). Métodos: Foi realizado um estudo retrospectivo e descritivo de intervenções realizadas em pacientes com hérnia de disco nos serviços de Traumatologia e Neurocirurgia, empregando-se as seguintes variáveis: idade, sexo, tipo de técnica, tempo de cirurgia, tempo de evolução, grau de satisfação e complicações. Foram formados dois grupos: instrumentação com barras dinâmicas e técnicas não instrumentadas, comparando os resultados de cada grupo. O software utilizado foi o SPSS v20.0. Resultados: Apresentamos 142 intervenções realizadas entre 2009 e 2012, 86 por instrumentação dinâmica e 56 por técnicas de descompressão sem instrumentação. Não foram observadas diferenças estatisticamente significativas entre os grupos de idade, sexo e tempo de evolução até a intervenção. Constataram-se diferenças estatisticamente significativas quanto ao tempo cirúrgico ( $p=0,001)$, sendo menor na técnica instrumentada. Com relação às complicações das técnicas, não houve diferença significativa nas re-operações nem nas infecções. Conclusões: Não foram encontradas diferenças significativas entre o uso de instrumentação com barras dinâmicas com respeito a outras técnicas cirúrgicas não instrumentadas no tratamento da hérnia de disco com mais de 6 meses de evolução nem a complicações e ao grau de satisfação dos pacientes.

Descritores: Deslocamento do disco intervertebral/terapia; Discotomia; Parafusos pediculares. 


\section{INTRODUCTION}

Chronic back pain is one of the greatest problems related to decreased quality of life of the patient. Nonetheless, the surgical approach to disc hernias of more than six months of evolution, associated with degenerative discopathies that do not respond to conservative treatment, continues to be a challenge. ${ }^{1}$

We often encounter studies in scientific journals that present poor disc hernia surgery outcomes within the context of degenerative pathology, and even with no degenerative pathology, in cases where they have evolved over time. ${ }^{2}$

Thus, the concept of postdiscectomy syndrome has emerged to define a clinical profile of the recurrence of lumbar and radicular pain related to periradicular fibrosis, instability of the operated segment, degeneration of the segment, etc. ${ }^{3}$

Distinct surgical techniques have been developed to treat this problem, among which is included dynamic stabilization of the operated segment. ${ }^{4}$ The goal of this technique is to stabilize the segment, without fusion in order to reduce mobility and also to reduce and/or prevent postsurgical degeneration..$^{5,6}$ Other indications, not addressed in this study, are used to prevent the adjacent segment syndrome, only applicable in cases of fusion with or without instrumentation. ${ }^{7}$

Our objective is to compare the results of treatment in patients with low back pain and radiculalgia secondary to a herniated disc associated with disc degeneration, using instrumentation with pedicle screws and dynamic rods, releasing the root without discectomy, with those of the other technique still considered the gold standard for disc surgery, microdiscectomy with or without foraminotomy. Given that we compared two different techniques, we analyzed whether the impingement of the intervertebral disc, a recognized cause of the onset of fibrosis, ${ }^{8}$ and whether laminectomy and/or foraminotomy, possible causes for segmental instability, ${ }^{9}$ would have better clinical outcomes in reducing possible postlaminectomy segmental instability than to not carry out discectomy and than the use of dynamic stabilization.

\section{METHOD}

This was a retrospective review of the surgeries performed in patients with disc herniations by the Traumatolgy and Neurosurgery Services from 2009 to 2012.

The variables collected were: age, sex, BMI, type of technique used, surgical time, time of disease progression until surgery, patient satisfaction level $(1=$ poor, $2=$ average, $3=$ good, $4=$ excellent $)$, and the presence of complications (infections, failure of the osteosynthesis materials, reinterventions, follow-up in pain treatment centers).

The study was approved by Institutional Rewiew Board of the Hospital de León (the number of the research protocol was 1622), the patients signed the informed consent form for participation in the study, and all the data was anonymized.

The inclusion criteria were: Patients between 18 and 65 years of age, who suffered from low back pain and radiculalgia secondary to disc herniation associated with disc degeneration at a single level (confirmed by magnetic resonance imaging), and who underwent medical treatment and rehabilitation for at least six months. All the patients were informed about the surgical procedures and signed the informed consent form. We excluded patients with non-lumbar disc hernias or without medical histories, patients with less than six months of disease progression, who had undergone previous surgeries, and who had stenosis, listhesis, segmental instability, infections, tumors, scoliosis, vertebral fractures, or severe systemic illnesses.

We organized the patients into two groups by technique: one group with dynamic rod instrumentation and release of the compressed root without discectomy and the other with simple discectomy. We compared the results obtained in each group. For the statistical analysis, we used SPSS v20.0 software. The level of significance was established at 95\%.

\section{Surgical intervention and indication}

The patients were operated in the prone position under general anesthesia. They received prophylactic antibiotics with the anesthetic induction and two hours prior to the surgery. The patients who underwent surgery in the Neurosurgery Service received antibiotic prophylaxis 90 minutes before the surgery began. The level to be operated on was determined intraoperatively using a fluoroscope.

\section{Release and dynamic stabilization technique}

Pedicular instrumentation system with dynamic rods: The conventional technique without a microscope was used. An incision was made in the skin and then a dissection by planes with an electric scalpel. A foraminotomy or a flavectomy was performed to decompress the nerve root. The procedure continued with the placement of transpedicle screws assisted by a fluoroscope and the dynamic rod was installed. Discectomies or bone grafts (arthrodesis) were not performed in any of the cases.

\section{Simple discectomy technique}

Microdiscectomy: An incision is made in the skin, then dissection by planes using an electric scalpel or a cold scalpel and scissors is performed. Once the space is located, it is confirmed using the fluoroscope. From this point on, the procedure continues under the microscope. Once the space where the disc hernia is found, the root is located and the protruding disc and the foraminal disc fragments are removed, and then we move on to the discectomy. The patient receives a vial of extended release corticosteroid and a compound to prevent fibrosis. A foraminotomy is performed in cases where the space is compromised and a laminectomy when there is a disk fragment sequestered inside the channel or in cases of large volume disc hernias.

\section{RESULTS}

One hundred and forty-two patients, who underwent surgery between 2009 and 2012, with an average follow-up time of 44 months (ranging from 16-65 months), were included in the study. Instrumentation with dynamic rods was used in 86 patients and other techniques without instrumentation were used in the other 56 patients (18 patients underwent microdiscectomies with foraminotomy and 38 , microdiscectomies without foraminotomy). The distribution by sex was 70 males (49\%) and 72 females (51\%). The average age was 43.67 years (ranging from 21 to 65 years of age) and the average BMI was 25.25 (from 15.4 to 36.9). The average surgical time was 109 minutes (ranging from 45 to 275 minutes). The average clinical follow-up time prior to surgery was 17.9 months (ranging from 6 to 192 months). The most common locations were L4-L5 right (39 patients, 25.7\%), L5-S1 left (39 patients, 25.7\%), L4-L5 left (35 patients, 23\%), and L5-S1 right (25 patients, 16.4\%).

We did not observe any statistically significant differences in the composition of the groups in terms of age, sex, time of disease progression until the intervention, BMI, location of the hernia, or duration of postoperative follow-up. Statistically significant differences were observed $(p=0.001)$ between surgical times, with an average of 84 minutes \pm 22.58 ) for the dynamic technique and 150 minutes $( \pm 38.76)$ for the discectomies. (Table 1)

There were 25 reinterventions (16.4\%), 5 infections (3.3\%), and 13 referrals to the pain treatment center for follow-up (8.6\%). There were no significant differences between the comparison groups either for reinterventions $(p=0.344)$, infections $(p=0.447)$, or for follow-up in the pain treatment center $(p=0.706)$. (Table 2$)$

There was no significant difference either in the levels of patient satisfaction between the groups $(p=0.825)$, averaging higher than 3 in both groups, or in terms of responses to the question about whether they would undergo the surgery again (chi square $p=0.103$ ).

The only point where differences were encountered was in the use of corticosteroids prior to surgery, higher in the group of patients without instrumentation $(p=0.001)$.

The population sample with the lowest satisfaction with the surgery (those who left a poor or average rating, who would not recommend the technique, and who would not undergo the surgery again) was a group of 23 patients (65\% of whom were women) with an average age of 44 years \pm 8 , slightly overweight $(B M I=25.6)$, with $L 4$ - L5 involvement (52\%), and being treated with psychoactive drugs (56\%). 
Table 1. Comparison of variables between the instrumented technique and discectomy.

\begin{tabular}{c|c|c|c|c}
\hline & \multicolumn{2}{c|}{ Technique } & \multirow{2}{*}{$\begin{array}{c}\text { Statistical } \\
\text { Significance }\end{array}$} \\
\cline { 2 - 4 } & Instrumentation & Discectomy & 0.111 \\
\hline \multicolumn{2}{c|}{ Age } & 44.3 & 42.7 & 0.835 \\
\cline { 2 - 4 } & Memale & 43 & 27 & 0.311 \\
\hline $\begin{array}{c}\text { Time since the } \\
\text { surgery (months) }\end{array}$ & 43 & 29 & 0.362 \\
\hline \multicolumn{2}{c|}{ BMI } & 25.7 & 25.2 & 0.256 \\
\hline $\begin{array}{c}\text { Time of postoperative } \\
\text { follow-up (months) }\end{array}$ & 42.9 & 45.7 & 0.002 \\
\hline $\begin{array}{c}\text { Surgical time } \\
\text { (mintues) }\end{array}$ & 84 & 150 & \\
\hline
\end{tabular}

Table 2. Complications.

\begin{tabular}{c|c|c|c}
\hline & \multicolumn{2}{|c|}{ Technique } & P value \\
\cline { 2 - 4 } & Instrumentation & No instrumentation & Number of \\
reinterventions & 12 & 13 & 0.344 \\
\hline Number of infections & 2 & 3 & 0.447 \\
\hline $\begin{array}{c}\text { Number of patients } \\
\text { in follow-up in pain } \\
\text { treatment centers }\end{array}$ & 8 & 5 & 0.706 \\
\hline
\end{tabular}

The main complications reported in the dynamic approach group were residual pain and instrumentation failure, while in the other technique group hernia recurrence and dural injuries were predominant.

\section{DISCUSSION}

Degenerative disc disease and disc hernias are the most common problems in patients with low back pain ${ }^{10}$ and one of the most common causes of work leave. Nevertheless, the treatment of disc hernias is very controversial and there are a multitude of studies that present contradictory conclusions. ${ }^{11}$

For example, the results published by Weber ${ }^{10}$ reported that prolonged conservative treatment has outcomes after four years of follow-up similar to those achieved through early surgery. After this, several observational cohort studies were conducted that presented worse results from conservative treatment as compared to early surgery. They came to the conclusion that, after two months of sciatica, outcomes from conservative treatment are worse than those from surgical intervention. ${ }^{12,13}$ All of these results must be viewed with caution because the studies were not based on randomized populations and included patients who did not receive the same analgesic regimens or follow the same recommendations, making the outcomes not totally comparable.

In their observational studies, Nygaard et $\mathrm{al}^{14}{ }^{14}, \mathrm{Ng}$ and Sell ${ }^{15}$ concluded that surgery following from eight to twelve months of sciatica produced worse results than surgery performed earlier. However, we must keep in mind that it is difficult to make patients with persistent sciatica wait for 8-12 months of conservative treatment. Furthermore, this study should have been conducted with a randomized population, recording the symptoms as a function of time, as was not the case.

However, the general conclusions from the random trials conducted by Weinstein, Osterman, and Butterman do not suggest unsatisfactory outcomes from long-term conservative treatment. ${ }^{16-18}$

From all these results, we can conclude that early surgery (a clinical history of sciatica for 6-12 weeks) does not lead to better long-term results. The only benefits are a faster decline of the radiculopathy and an earlier recovery. This, however, can be considered a valuable advantage for the part of the population that is unable to, unwilling to, or cannot wait for the natural course of the disease or for the possibility of a delayed surgery if necessary.
The general recommendation is to wait for a period of 6 to 12 weeks after the onset of symptoms, except in cases of cauda equina or rapid loss of motor function. ${ }^{13,19}$ However, taking all the studies into account, perhaps we should rethink this indication because in our study we excluded patients who had undergone surgery after less than 6 months of progression.

Currently, there are numerous techniques for treating degenerative disc disease with debatable results. ${ }^{15}$ In the last century, surgical treatment for pain in degenerative disc diseases began with discectomies and decompressions. The first lumbar discectomy was performed by Mixter and Barr ${ }^{20}$ in 1934, and became the most used technique. Today, the microdiscectomy, a less traumatic procedure that permits smaller incisions of the skin and muscle tissue, is being performed. The simple discectomy and the microdiscectomy are considered to be the gold standards for the surgical treatment of lumbar disc hernias. ${ }^{2}$ However, these techniques have not yielded good results in the treatment of chronic back pain following disc suppression, since low back pain and sciatica persisted in up to $40 \%$ of cases, although in only $20 \%$ in our sample.

Back pain and sciatica following discectomy may be due to segmental instability and to the concept of chronic degenerative instability.22,24 Formerly, fixation systems were static, but today dynamic stabilization systems are beginning to be used. These devices preserve movement and can be classified as prosthetic or dynamic. With prosthetic devices, the disc, the nucleus, and the facet joints are completely substituted by the prosthesis, replacing the anatomic structure and functions of the lumbar movement segment. These systems are technically more complex, require longer surgical time, and have more complications. ${ }^{2}$

Instead, dynamic stabilization devices function together with the movement segment, without replacing any anatomical structure. Semirigid fixation is the most commonly used term to describe these devices, a questionable concept and one we do not share since dynamic systems do not produce fusion. In fact, there is no graft involved, it is only intended to offer stabilization without the tension that conventional rigid fixation produces.

The devices restrict movement to a certain extent and allow the load to be shared between the device and the movement segment. For the long-term survival of the device, the loads and the movement must be shared with the device, which complements the kinematics of the segment in motion. If this does not happen, the device can end up failing from overuse (breakage or loosening). This must be avoided since the device must endure for an indefinite period of time. They bring the advantages of easy conversion to conventional stabilization or replacement of parts, compatibility with minimally invasive procedures, and restoration of anatomical lordosis. ${ }^{25}$

Dynamic stabilization is used to eliminate lumbar pain and stabilize degenerated discs. These systems enable a more physiological transmission of forces between the anterior and posterior components of the lumbar spine, while maintaining mobility and controlling abnormal movements in the lumbar segment. ${ }^{26,27}$ These semirigid stabilization systems restore normal spine functions and protect the adjacent segments. ${ }^{27,28}$ In our review, there was only one case of degeneration of the adjacent disk.

In our review of the articles that analyze the outcomes of treatments for disc herniations, we observed that there are discrepancies among the scientific works in terms of methodology, surgical outcomes, and follow-up. Perhaps the main issues are data collection bias and the great variability among the individual characteristics of the patients presented by the different studies. ${ }^{29}$

In our study, the fact that the patients were separated into two cohorts, each of which was operated, treated, and analyzed by a different service was a limitation because the results are not entirely comparable.

\section{CONCLUSIONS}

There are no significant differences between the use of dynamic rods and other non-instrumented surgical techniques in the treatment of disc herniations with more than 6 months of evolution in terms of complications or of the level of patient satisfaction.

We did find a statistically significant difference between the 
surgical times required, which was shorter in the patients with dynamic instrumentation.

We also observed a statistically significant difference in the proportion of corticosteroids used prior to surgery, which was lower among the patients with dynamic instrumentation.

Because few long-term studies have been published comparing the different surgical techniques used for the treatment of disc herniations within the context of degenerative disc disease, longer-term studies need to be conducted and compared with other alternative surgical techniques.

All the authors declare that there are no potential conflicts of interest regarding this article.

CONTRIBUTION OF THE AUTHORS: Each author made significant individual contributions to the development of the manuscript. They all reviewed and approved the final version of the work. MLSH Data collection, bibliographical research, and writing of the manuscript. EID Data collection and analysis. AAC Data analysis and interpretation. JBN Critical review of the manuscript. SSC Bibliographical research. ALMS Data collection. MFG Design and critical review of the study.

\section{REFERENCES}

1. Nyström B. Spinal fusion in the treatment of chronic low back pain: rationale for improvement. Open Orthop J. 2012;6:478-81.

2. Mirza SK, Deyo RA. Systematic review of randomized trials comparing lumbar fusion surgery to nonoperative care for treatment of chronic back pain. Spine (Phila Pa 1976). 2007;32(7):816-23.

3. Anandjiwala J, Seo JY, Ha KY, Oh IS, Shin DC. Adjacent segment degeneration after instrumented posterolateral lumbar fusion: a prospective cohort study with a minimum five-year follow-up. Eur Spine J. 2011;20(11):1951-60.

4. KanerT, Ozer AF. Dynamic stabilization for challenging lumbar degenerative diseases of the spine: a review of the literature. Adv Orthop. 2013;2013:753470.

5. Coe JD, Kitchel SH, Meisel HJ, Wingo CH, Lee SE, Jahng TA. NFlex Dynamic Stabilization System : Two-Year Clinical Outcomes of Multi-Center Study. J Korean Neurosurg Soc. 2012;51(6):343-9.

6. Sénégas J, Vital JM, Pointillart $V$, Mangione P. Clinical evaluation of a lumbar interspinous dynamic stabilization device (the Wallis system) with a 13-year mean follow-up. Neurosurg Rev. 2009;32(3):335-41.

7. Sengupta DK, Herkowitz HN. Pedicle screw-based posterior dynamic stabilization: literature review. Adv Orthop. 2012;2012:424268.

8. Ross JS, Robertson JT, Frederickson RC, Petrie JL, Obuchowski N, Modic MT, deTribolet N. Association between peridural scar and recurrent radicular pain after lumbar discectomy: magnetic resonance evaluation. ADCON-L European Study Group. Neurosurgery. 1996;38(4):855-61.

9. Mullin BB, Rea GL, Irsik R, Catton M, Miner ME. The effect of postlaminectomy spinal instability on the outcome of lumbar spinal stenosis patients. J Spinal Disord. 1996;9(2):107-16.

10. Weber H. Lumbar disc herniation. A controlled, prospective study with ten years of observation. Spine (Phila Pa 1976). 1983;8(2):131-40.

11. Peul WC, van den Hout WB, Brand R, Thomeer RT, Koes BW; Leiden-The Hague Spine Intervention Prognostic Study Group. Prolonged conservative care versus early surgery in patients with sciatica caused by lumbar disc herniation: two year results of a randomised controlled trial. BMJ. 2008;336(7657):1355-8.

12. Hurme M, Alaranta $H$. Factors predicting the result of surgery for lumbar intervertebral disc herniation. Spine (Phila Pa 1976). 1987;12(9):933-8.

13. Rothoerl RD, Woertgen C, Brawanski A. When should conservative treatment for lumbar disc herniation be ceased and surgery considered? Neurosurg Rev. 2002;25(3):162-5

14. Nygaard OP, Kloster R, Solberg T. Duration of leg pain as a predictor of outcome after surgery for lumbar disc herniation: a prospective cohort study with 1-year follow up. J Neurosurg. 2000;92(2 Suppl):131-4.

15. Ng LC, Sell P. Predictive value of the duration of sciatica for lumbar discectomy. A prospective cohort study. J Bone Joint Surg Br. 2004;86(4):546-9.

16. Jacobs WC, Arts MP, van Tulder MW, Rubinstein SM, van Middelkoop M, Ostelo RW, Verhagen AP, Koes BW, Peul WC. Surgical techniques for sciatica due to herniated disc, a systematic review. Eur Spine J. 2012;21(11):2232-51.

17. Osterman $H$, Seitsalo S, Karppinen J, Malmivaara A. Effectiveness of microdiscectomy for lumbar disc herniation: a randomized controlled trial with 2 years of follow-up. Spine (Phila Pa 1976). 2006;31(21):2409-14.

18. Buttermann GR. Treatment of lumbar disc herniation: epidural steroid injection compared with discectomy. A prospective, randomized study. J Bone Joint Surg Am. 2004;86-A(4):670-9.

19. Deyo RA. Back surgery--who needs it? N Engl J Med. 2007;356(22):2239-43.

20. Mixter WJ, Barr JS. Rupture of the intervertebral disc with involvement of the spinal canal. N Engl J Med. 1934;211:210-5.

21. Striffeler H, Gröger U, Reulen HJ. "Standard" microsurgical lumbar discectomy vs. "conservative" microsurgical discectomy. A preliminary study. Acta Neurochir (Wien). 1991;112(1-2):62-4.

22. Caspar W, Campbell B, Barbier DD, Kretschmmer R, Gotfried Y. The Caspar microsurgical discectomy and comparison with a conventional standard lumbar disc procedure. Neurosurgery. 1991;28(1):78-86.

23. Vaughan PA, Malcolm BW, Maistrelli GL. Results of L4-L5 disc excision alone versus disc excision and fusion. Spine (Phila Pa 1976). 1988;13(6):690-5.

24. Panjabi MM. Clinical spinal instability and low back pain. J Electromyogr Kinesiol. 2003;13(4):371-9.

25. Schwarzer AC, Aprill CN, Derby R, Fortin J, Kine G, Bogduk N. The relative contributions of the disc and zygapophyseal joint in chronic low back pain. Spine (Phila Pa 1976). 1994;19(7):801-6.

26. Sengupta DK. Dynamic stabilization devices in the treatment of low back pain. Neurol India. 2005;53(4):466-74.

27. Bothmann M, Kast E, Boldt GJ, Oberle J. Dynesys fixation for lumbar spine degeneration. Neurosurg Rev. 2008;31(2):189-96.

28. Kaner T, Sasani M, Oktenoglu T, Cosar M, Ozer AF. Utilizing dynamic rods with dynamic screws in the surgical treatment of chronic instability: a prospective clinical study. Turk Neurosurg. 2009;19(4):319-26.

29. Grieve GP. Movilizacion de la columna vertebral: Manual basico de metodo clinico. Barcelona: Paidotribo; 2001. 